Article

\title{
Enhanced Nanofiltration Process of Thin Film Composite Membrane Using Dodecyl Phenol Ethoxylate and Oleic Acid Ethoxylate for Oilfield Calcite Scale Control
}

\author{
Saedah R. Al-Mhyawi ${ }^{1}$, Mahmoud F. Mubarak ${ }^{2, *}$, Rasha Hosny ${ }^{3}$, Manal Amine ${ }^{4}$, Omnia H. Abdelraheem ${ }^{5}$, \\ M. A. Zayed ${ }^{6}$, Ahmed H. Ragab ${ }^{7}$ (D) and Abeer El Shahawy ${ }^{8, *(D)}$
}

1 Department of Chemistry, College of Science, University of Jeddah, Jeddah 21419, Saudi Arabia; sral-mhyawi@uj.edu.sa

2 Petroleum Application Department, Egyptian Petroleum Research Institute (EPRI), Nasr City, Cairo 11727, Egypt

3 Production Department, Egyptian Petroleum Research Institute (EPRI), Nasr City, Cairo 11727, Egypt; dr.rashahosny@yahoo.com or rashahosny@epri.sci.eg

4 Processes Design \& Development Department, Egyptian Petroleum Research Institute (EPRI), Nasr City, Cairo 11727, Egypt; manal_amin2000@yahoo.com

5 Engineering Sciences Department, Faculty of Engineering, Beni-Suef University, Beni-Suef 62511, Egypt; omnia_hassan55@yahoo.com

check for updates

Citation: Al-Mhyawi, S.R.; Mubarak, M.F.; Hosny, R.; Amine, M.; Abdelraheem, O.H.; Zayed, M.A.; Ragab, A.H.; El Shahawy, A. Enhanced Nanofiltration Process of Thin Film Composite Membrane Using Dodecyl Phenol Ethoxylate and Oleic Acid Ethoxylate for Oilfield Calcite Scale Control. Membranes 2021, 11,855. https://doi.org/10.3390/ membranes 11110855

Academic Editors: Myoung Jun Park, Dong Han Seo and Grace M. Nisola

Received: 27 September 2021

Accepted: 2 November 2021

Published: 4 November 2021

Publisher's Note: MDPI stays neutral with regard to jurisdictional claims in published maps and institutional affiliations.

Copyright: (c) 2021 by the authors Licensee MDPI, Basel, Switzerland. This article is an open access article distributed under the terms and conditions of the Creative Commons Attribution (CC BY) license (https:// creativecommons.org/licenses/by/ $4.0 /)$.
6 Chemistry Department, Faculty of Science, Cairo University, Giza 12613, Egypt; Zayed@sci.cu.edu.eg

7 Department of Chemistry, Faculty of Science, King Khalid University, Abha 62224, Saudi Arabia; ahrejab@kku.edu.sa

8 Department of Civil Engineering, Faculty of Engineering, Suez Canal University, Ismailia 41522, Egypt

* Correspondence: fathy8753@epri.sci.eg or fathy8753@yahoo.com (M.F.M.); abeer_shahawi@eng.suez.edu.eg (A.E.S.)

\begin{abstract}
This research studied the enhancing effect on the nanofiltration composite (TFCNF) membrane of two non-ionic surfactants on a thin-film composite nanofiltration membrane (TFCNF) for calcite scale $\left(\mathrm{CaCO}_{3}\right)$ inhibition in oilfield application to develop a multifunctional filtration system: nanofiltration, antiscalant, and scale inhibitors. The effectiveness of dodecyl phenol ethoxylate (DPE) and oleic acid ethoxylate (OAE) as novel scale inhibitors were studied using the dynamic method. Scaling tests on the membrane were performed to measure the scaling of the inhibited membrane with and without scale inhibitors for salt rejection, permeability, and flux decline. The results revealed that the TFCNF membrane flux decline was improved in the presence of scale inhibitors from $22 \%$ to about $15 \%$. The rejection of the membrane scales increases from $72 \%$ for blank membranes, reaching $97.2 \%$ and $88 \%$ for both DPE and OAE, respectively. These confirmed that scale inhibitor DPE had superior anti-scaling properties against calcite deposits on TFCNF membranes. Inhibited scaled TFCNF membrane was characterized using environmental scanning electron (ESEM), FTIR, and XRD techniques. The results of the prepared TFCNF membrane extensively scaled by the calcite deposits were correlated to its morphology.
\end{abstract}

Keywords: produced water treatment; oilfield calcite scale control; scales precipitation; scale inhibitors; non-ionic surfactants; alkylethoxylate; nanofiltration membrane

\section{Introduction}

Scale formation of produced water [1,2] generated during oil or natural gas exploitation may occur due to the incompatibility between the formation water and the injected seawater [3]. The result deposits adhere near the surfaces of the well-producing tubing, perforations, tubing, sub-sea equipment, which accumulates over time and causes problems in reservoirs, topside facilities, and impairs oil production [4]. Calcium carbonates, "calcite", are scale-formed in the oil and gas industry, causing high costs and significantly reducing production rates and equipment damages [5]. 
Membrane separation is categorized as advanced wastewater treatment technology and has the advantages of high operating efficiency, easy scale-up, and less space demand [6-8]. Nanofiltration (NF) has been assigned as an efficient water treatment techniquebecause of its ability to treat a large variety of waters. As the NF membrane recovery percentage increases, the concentration of these sparingly soluble minerals salts also increases in the membrane, resulting in salt saturation on the membrane causing inorganic scaling $[9,10]$. Consequently, scales decrease membrane permeate flux and reduce life [11]. As a result, the consumption of scale inhibitors ensures the stability and duration of the system; consequently, much attention has been paid to scale inhibitor research [12-15]. Therefore, the selected antiscalants in specific applications have different capabilities for inhibiting scales in the NF membrane. The scale inhibitors holdup the crystal formation through slowing induction time, leading to a delay of crystal growth [16].

In PW treatment, scale inhibitors decrease scale residues on the membrane surface in a membrane-operated water treatment plant $[17,18]$. Many antiscalants fight to scale and fouling by attaching to the contaminants in the water, thereby inhibiting it from depositing on the membrane surface $[19,20]$. These contaminants are finally discarded in the drain of the NF [21]. Theantiscalants are available with variable chemistries based on phosphates, phosphonates, maleic, acrylates, and carboxylic acids [22,23].

Alkylphenol ethoxylate (APE) is one of the most widely used classes of surfactants.APEs are soluble in water and assist in the dispersion of dirt and grease from stained surfaces into water. APEs are essential to many industrial applications such astextiles, paper, coatings, plastics, pesticides, lubricants, and fuels [24]. Synthetic surfactants differ significantly in structure but are mainly composed of alkyl or alkylphenol groups joined to an anionic or non-ionic hydrophilic moiety. These compounds are generally safe and eco-friendly. Besides, they do not lead to pollution problems because they are subjected to biodegradation by micro-organisms existing in soils and surface waters [25].

The objective of this paper is to improve water treatment via decreasing calcite scale on TFCNF membranes surface. Therefore, in this research, two new scale inhibitors, dodecyl phenol ethoxylate(DPE) and oleic acid ethoxylate (OAE),were prepared and investigated through the spectroscopic techniques FTIR and HNMR. The role of DPE and OAE in calcite scaling control was evaluated depending on the change of permeate flux decline compared to that of the bared TFCNF membrane. The PVDF polymer is selected and used due to its following advantages; a high porosity and high water permeability, high chemical stability than polyvinyl chloride or polyethersulfone when it is used as a support, much lower layer thickness than other polymers, which saves in the amount used, enhances salt scales rejection without causing the injury of inner pores structures during water desalination processing, easy to recycle the used membrane, adding a new economic effect of using PVDF as membrane support.Scaled inhibited TFCNF membrane characterization via ESEM, FTIR, and XRD analysis were investigated. Moreover, the membrane scaling control mechanism in DPE and OAE was illustrated using different calcite solution concentrations.

\section{Materials and Experimental}

\subsection{Materials}

For the preparation of scale inhibitors, an ethylene oxide cylinder with a valve was obtained from the Eastern Company for Industrial Gases, Egypt; Dodecyl phenol (commercial grade) was purchased from Prolabo, Oleic acid (99\%, from Merck-Schuchardt), and potassium hydroxide from Aldrich). Sodium carbonate $\left(\mathrm{Na}_{2} \mathrm{CO}_{3}\right)$ and calcium chloride $\left(\mathrm{CaCl}_{2}\right)$ were purchased from Aldrich. The solution $\mathrm{pHw}$ as adjusted by using $\mathrm{NaOH}$ and $\mathrm{HCl}$ solution. For membrane preparation, dimethyl-acetamide (DMAc), dichloromethane (DCM), chloroform, n-butanol, octylamine (OA), octadecylamine (ODA), Poly-vinylidene fluoride $(\mathrm{PVDF})$ with molecular weight equal to $5.34 \times 105 \mathrm{~g} \cdot \mathrm{mol}^{-1}$, hydrazine monohydrate ( $80 \mathrm{vol} \%$ in $\mathrm{H}_{2} \mathrm{O}$ ) and phosphoric acid were obtained from Sigma Aldrich (Nottingham, UK). 


\subsection{Synthetic Produced Water}

Different concentrations of $\mathrm{Ca}^{2+}$ and $\mathrm{HCO}_{3}{ }^{-}$were prepared using $\mathrm{CaCl}_{2}$ and $\mathrm{NaHCO}_{3}$, as illustrated in Table 1 . The synthetic calcite brine symbolizes the oilfield-produced water with a similar salinity, ionic composition, and $\mathrm{pH}$ value. Brine is synthesized by dissolving inorganic salts in deionized water. These $\mathrm{CaCl}_{2}$ and $\mathrm{NaHCO}_{3}$ solutions were prepared individually by weighing salts and dissolving them in deionized water. Before the experiment runs, brine is diluted 1:1 and filtered through filter paper $(0.45 \mu \mathrm{m}) . \mathrm{NaOH}$ and $\mathrm{HCl}$ solution was used for each test to adjust the $\mathrm{pH}=7.81$. Before being mixed, $\mathrm{CaCl}_{2}$ and $\mathrm{NaHCO}_{3}$ solutions were allowed to equilibrate with carbon dioxide in the atmosphere for $24 \mathrm{~h}$.

Table 1. Composition of synthetic produced water (PW).

\begin{tabular}{cccc}
\hline \multicolumn{2}{l}{ Concentration of Ions $(\mathbf{m g} / \mathbf{L})$} & Density $(\mathrm{g} / \mathrm{cc})$ & $\mathbf{1}$ \\
\hline $\mathrm{Na}^{+}$ & 2000 & $\mathrm{pH}$ & 7.81 \\
$\mathrm{Cl}^{-}$ & 3437.46 & $\mathrm{TDS}$ & 6447.55 \\
$\mathrm{Ca}^{2+}$ & 400 & Salinity & 6010 \\
$\mathrm{HCO}_{3}{ }^{-}$ & 610 & Alkalinity as $\mathrm{HCO}_{3}{ }^{-}(\mathrm{mg} / \mathrm{L})$ & 599.53 \\
\hline
\end{tabular}

\subsection{Scale Inhibitors Preparation}

Synthesis of the employed surfactants was carried out in a lab-scale ethoxylation unit in our laboratories Figure 1. Dodecyl phenol ethoxylate (DPE) and oleic acid ethoxylate (OAE) surfactants were prepared by reacting gaseous ethylene oxide (pressure of 2.5-2.9 psi) with dodecyl phenol (DP) and oleic acid (OA), respectively, at $150-160{ }^{\circ} \mathrm{C}$ using $\mathrm{KOH}$ catalyst [26] Figures 2 and 3. Polyethylene glycols were formed as by-products and were removed according to the Weibull method [27]. Figure 4 explains the proposed mechanism of the reaction. After the removal of glycols, the obtained surfactants were characterized by FT-IR, and the average number (n) of oxyethylene (OE) units was determined through ${ }^{1} \mathrm{H}$ NMR [28].

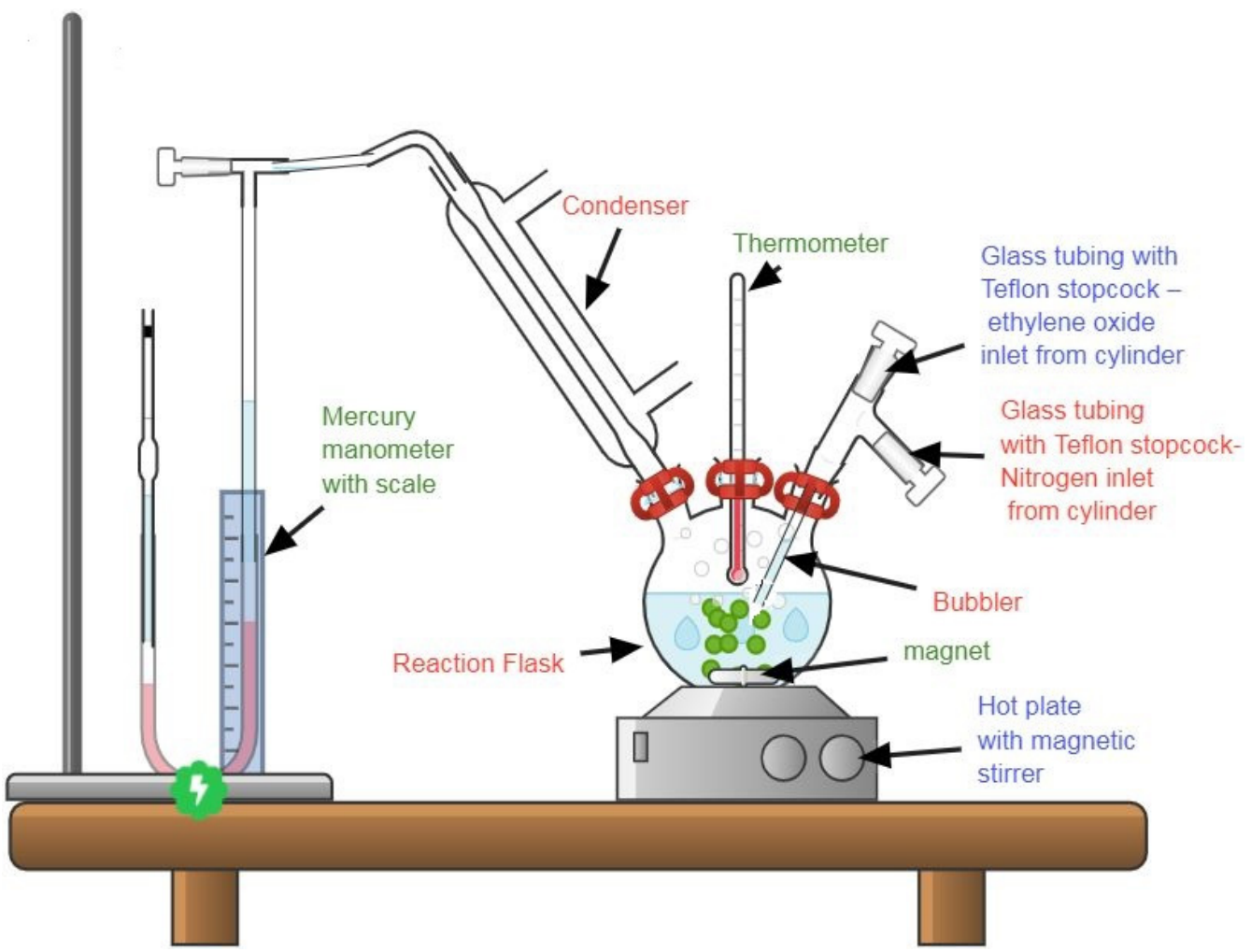

Figure 1. Batch laboratory-scale unit for ethoxylation reaction. 


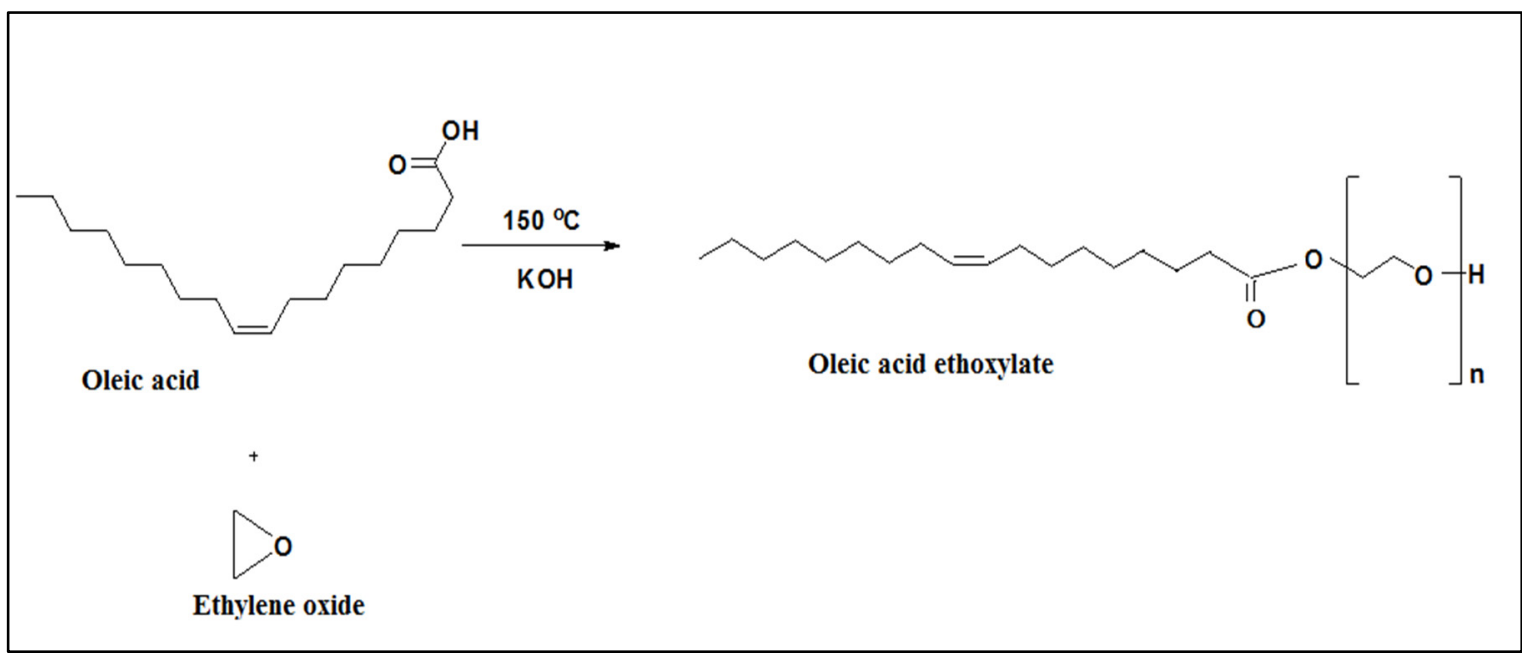

Figure 2. Synthesis approach for the preparation ofDodecyl phenol ethoxylate.

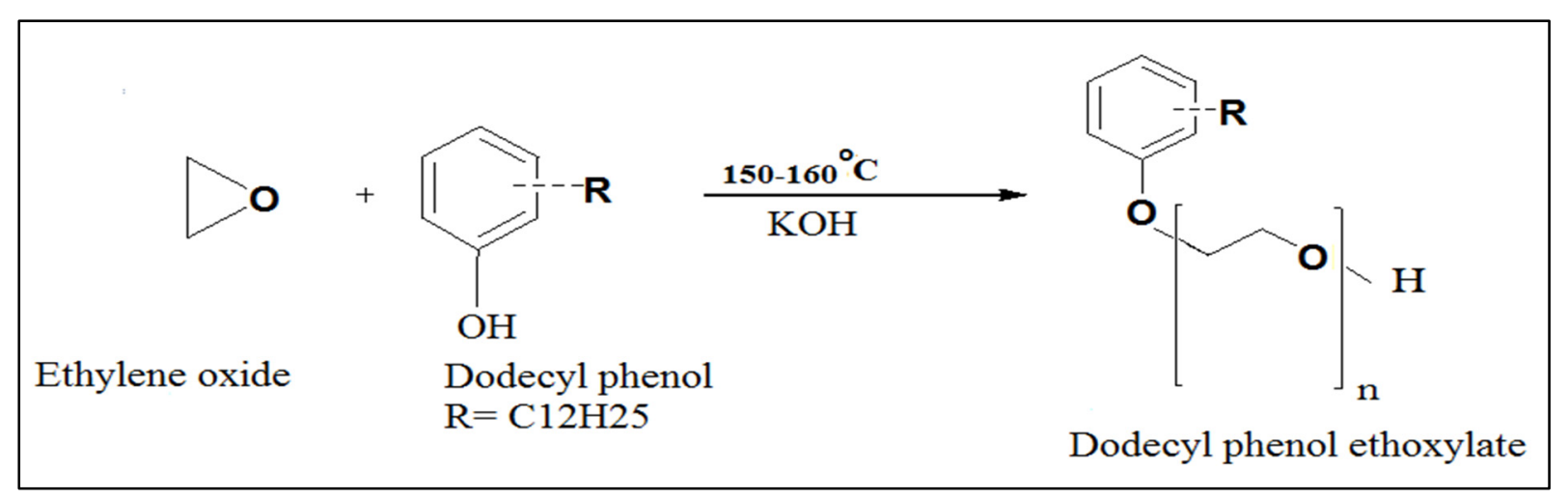

Figure 3. Synthesis route of oleic acid ethoxylate.

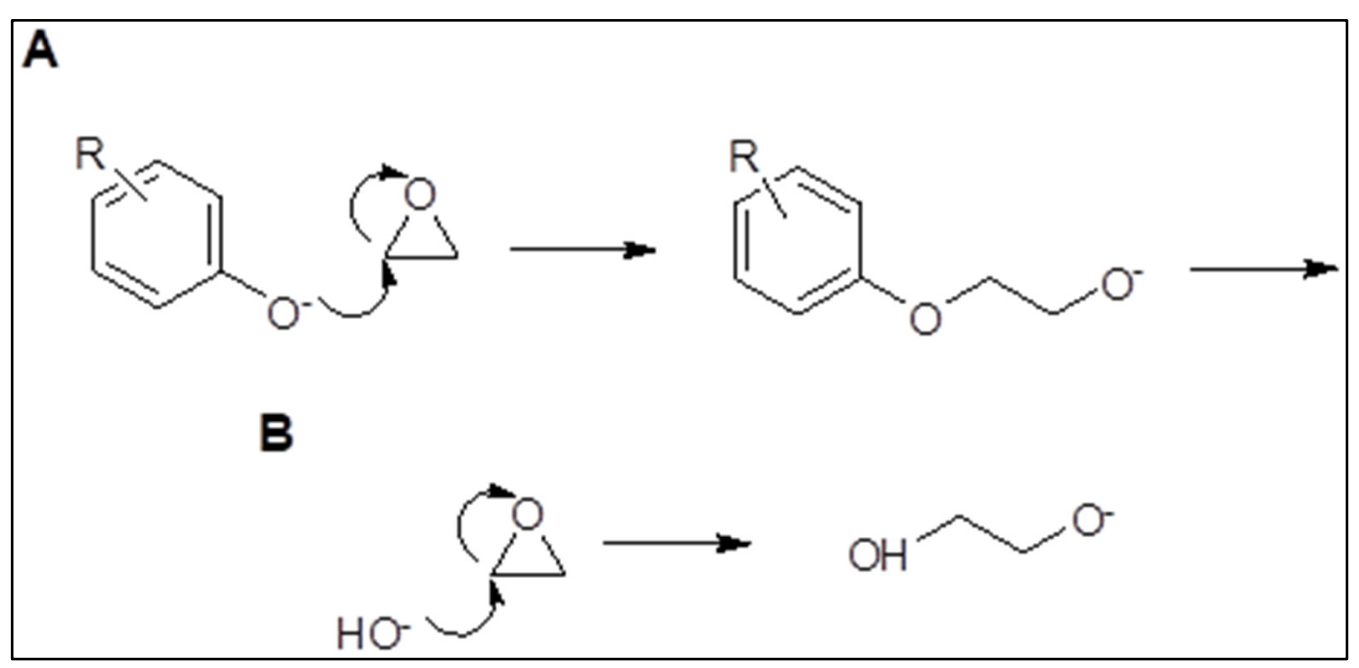

Figure 4. (A) Formation of majorethoxylate anion $(\mathrm{R}=\mathrm{C} 12 \mathrm{H} 25)$; (B) formation of minor by-product anion.

\subsection{Thin-Film Composite Nanofiltration Membrane Prepration (TFCNF)}

Porous polyvinylidene fluoride support "PVDF" was prepared according to Gao et al. [29] by the phase inversion technique, using the casting solution containing $18 \mathrm{wt} \%$ PVDF, $79 \mathrm{wt} \%$ DMAc, and $3 \mathrm{wt} \%$ phosphoric acids. Dope solutions were kept at $70{ }^{\circ} \mathrm{C}$ with stirring for $15 \mathrm{~h}$. The obtained homogeneous solution was left overnight without 
stirring to eliminate air bubbles. An automatic film applicator cast "PVDF" support at an application speed of $0.05 \mathrm{~m} \mathrm{~s}^{-1}$ using a $250 \mu \mathrm{m}$ knife set (Sheen $1133 \mathrm{~N}$, Nottingham, UK). The casted membrane was immersed for $10 \mathrm{~min}$ in a deionized water bath at room temperature and then kept in another water bath to dry at room temperature for $24 \mathrm{~h}$ to be used for thin-film composite nanofiltration membrane (TFCNF) preparation Curcio et al. [30].

Porous PVDF-supported TFCNF membrane was formed by the in-house built system using a dip-coating procedure. For all coating solutions, the polymer content was $4 \%$ by weight in chloroform, while the range of the filler loading was 0.01 to $0.25 \%$ by weight concerning the polymer weight. PVDF membrane support was dried overnight at room temperature before cutting into $(3 \mathrm{~cm} \times 10 \mathrm{~cm})$ coupons. TFCM was prepared by putting the PVDF supports in contact with the coating solutions for $10 \mathrm{~min}$ [31].

\subsection{Experiments of TFCNF Membrane Antiscaling}

The permeability and salt rejection of scaled inhibited behaviour of this membrane without and with scale inhibitors were measured by TFCNF membrane anti-scaling experiments. The jar-scale filtration setup was established to perform cross-flow membrane filtration experiments, as reported in Figure 5 [32].

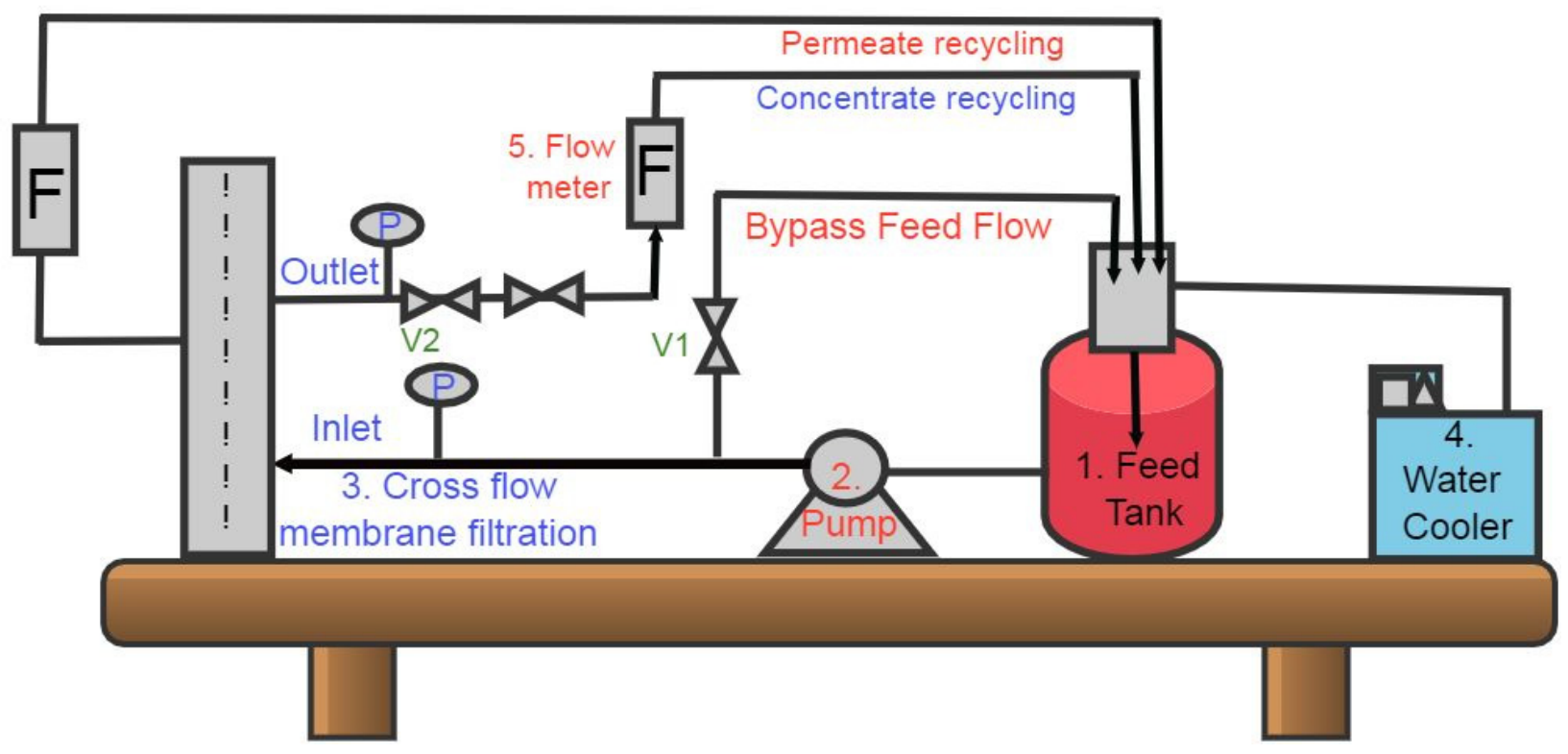

Figure 5. Diagram of membrane scaling experiments process flow.

Feed water was pumped from a $20 \mathrm{~L}$ tank with a high-pressure pump to the cross-flow membrane filtration cell (CF042, Sterlitech Corporation, Kent, WA, USA).

Figure 5 shows the recirculation of the concentrated water through the circulating water chiller back into the feed tank to control the feedwater temperature. Valves controlled the transmembrane pressure (TMP) in both feed water and concentrate water lines.

Feedwater filtration tests were performed with three initial $\mathrm{pH}$ values, "3.4, 7.0, and $10.0^{\prime \prime}$, to determine the effect of the initial feedwater $\mathrm{pH}$ on membrane performance. $0.1 \mathrm{~N} \mathrm{HCl}$ and $0.1 \mathrm{~N} \mathrm{NaOH}$ were used to adjust the solution $\mathrm{pH}$. Membrane flux was monitored throughout the filtration process and measured by the gravimetric method by weighing the permeability mass collected at certain time intervals. The feed and permeate $\mathrm{pH}$ was also monitored and measured with an AD $11 \mathrm{pH}$ meter (ADWA Kft., Europe). The feed and permeate samples were collected continuously throughout the entire filtration test to obtain membrane rejection rates. 
The Pure water permeation fluxes (PWP) were measured using Equation (1) at operating conditions $1 \mathrm{~L} / \mathrm{h}$ (flow rate), $35^{\circ} \mathrm{C}$ (temperature), 32 bar (pressure) [32].

$$
J_{w}(P W P)=\frac{Q_{p}}{\Delta P \cdot A}
$$

where $J w$ is membrane permeation flux $\left(\mathrm{L} / \mathrm{m}^{2}\right.$.h.bar), $Q_{p}(\mathrm{~L} / \mathrm{h})$ is permeate flow rate, $\Delta P$ (bar) is the trans-membrane pressure, and $A$ is the effective membrane area $\left(\mathrm{m}^{2}\right)$.

The effect of membrane scaling on salt rejection was calculated by measuring the conductivity (Digital Conductivity Meter, PCE-PHD 1-ICA) of permeate and feedwater to the scaling experiment end. The (\%R) membrane salt rejection was calculated using Equation (2).

$$
\% R=\frac{\left(C_{f}-C_{p}\right)}{C_{f}} \times 100
$$

where $C_{f}, C_{p}$ is the feed water and permeate conductivities.

The experiments were set up and divided into two steps. The first one consisted of conditioning the membranes using ultra-pure water for 1-2 h. In the second step, the feed water was the scaling solution, as the resulting time-dependent flux decline was tracked until it reached the stability of the permeate flux. The membrane flux $\left(\mathrm{J}, \mathrm{L} / \mathrm{m}^{2} / \mathrm{h}\right)$ was calculated using Equation (3) [33]:

$$
J=\frac{Q_{p}}{A}
$$

where $J$ is filtration flux, the normalized flux $J_{\mathrm{N}}$ is calculated using Equation (4):

$$
J_{N}=\frac{J}{J_{0}}
$$

where $J_{0}$ is an initial filtration flux at a given time.

Before each scaling experiment, the membranes were rinsed thoroughly with deionized water. Experiments were performed with fixed operating conditions under a recycling mode to maintain the feed water conditions as previously mentioned.

\subsection{Characterizations}

The characterizations of the prepared scale inhibitors DPE and OAE were investigated using FT-IR and ${ }^{1} \mathrm{HNMR}$.

Various techniques were applied to characterize the membrane surface before and after scaling experiments; ESEM, FT-IR, XRD. The hydrophilicity was measured by a contact angle device (OCA15Pro, Bruker, Germany). $2 \mu \mathrm{L}$ water drop was released onto the surface of the membrane mounted in the contact angle device.

Membrane surface scanned using Nova ${ }^{\mathrm{TM}}$ NanoSEM 50 Series (FEI Company) for ESEM analysis. FT-IR of the treated membrane was compared with that of the control membrane in spectra of $500-4000 \mathrm{~cm}^{-1}$ wavenumber range (Shimadzu FT-IR instrument).

The mineralogical composition and the crystalline nature of the scales deposited on the scaled membrane surface were analyzed via an X-ray diffractometer (XRD, D8 ADVANCE, Bruker, Germany).

Membranes samples evaluated mechanical properties (dog-bone shaped) applied using a universal tensile machine (LFplus $1 \mathrm{kN}$ Lloyd/New York, NY, USA). The uniaxial tensile testing method was performed at a rate of $5 \mathrm{~mm} / \mathrm{min}$. Tensile strength (MPa), Young's modulus (MPa), elongation at fracture (\%), and load at maximum load (N) were measured.

Brunauer-Emmett-Teller (BET) surface area analysis was applied to determine the membrane surface area and porosity. Before analyzing, $0.6 \mathrm{~g}$ dried membranes samples were degassed under vacuum in a surface area analyzer (AS-3012 AimSizer/Ningbo, 
China) for $10 \mathrm{~h}$ at $65^{\circ} \mathrm{C}$. All istruments used to characterized the prepared scale inhibitors and prepared membrane are found in Egyptian Petroelum Research Institute (EPRI).

\section{Results and Discussion}

3.1. Scale Inhibitors and Membrane Characterization

3.1.1. FT-IR of Scale Inhibitors

The FT-IR spectra (Figures 6 and 7) of the prepared non-ionic compounds showed the most characteristic band of ethoxylate formation, which is a band of $v \mathrm{C}-\mathrm{O}-\mathrm{C}$ at $\sim 1100 \mathrm{~cm}^{-1}$ [26].

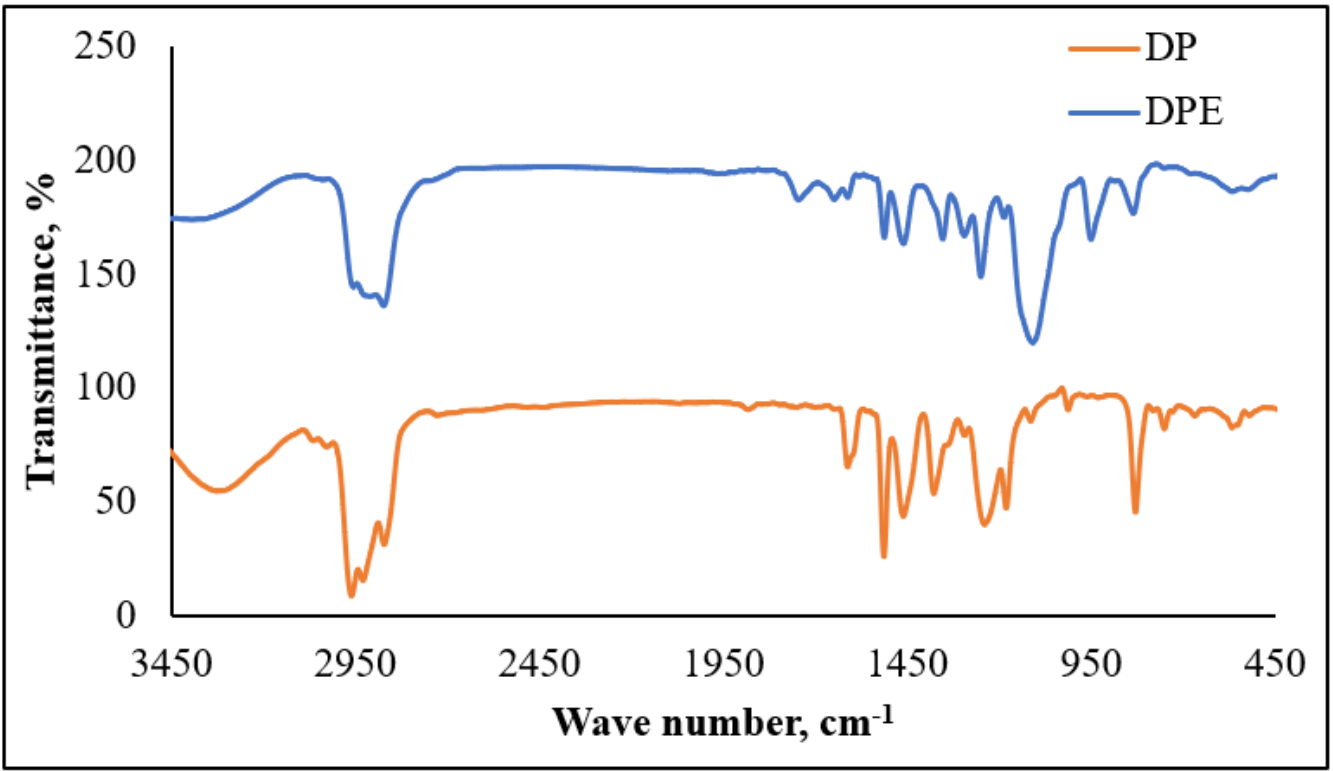

Figure 6. FTIR of dodecyl phenol (DP) and dodecyl phenol ethoxylate (DPE).

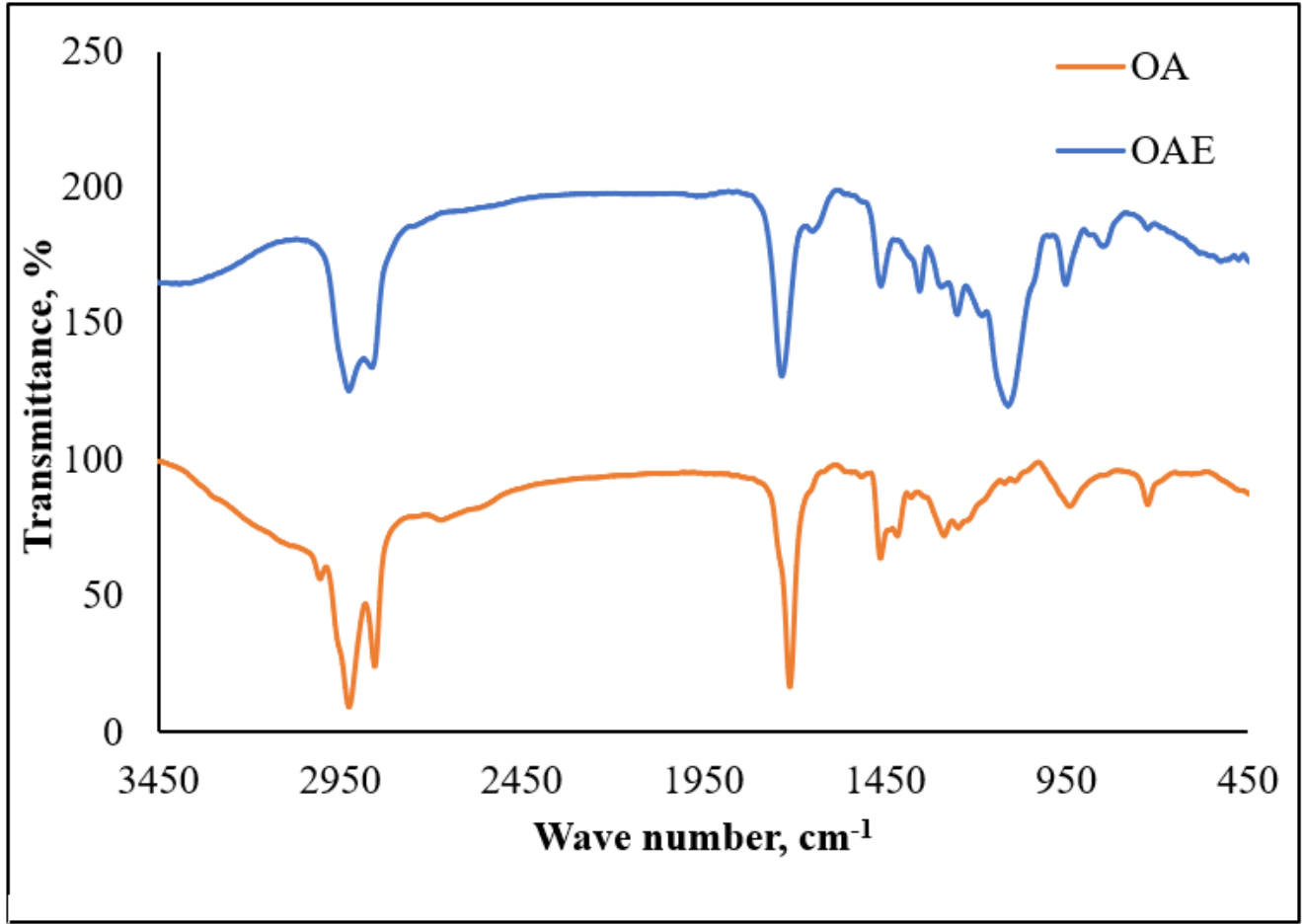

Figure 7. FTIR of oleic acid (OA) and oleic acid ethoxylate (OAE). 


\subsubsection{H-NMR for Scale Inhibitors}

${ }^{1} \mathrm{H}-\mathrm{NMR}$ spectra of the prepared non-ionic surfactants were obtained using Varian Mercury $300 \mathrm{Mz}$ spectrophotometer. DMSO $(2.47,2.51 \delta)$ was the used solvent for the samples. Figure 8a shows the spectra of oleic acid ethoxylate (OAE), which was estimated to have 12.06 as an average number of oxyethylene (OE) units adducted per oleic acid molecule. The spectra show a strong signal at about 3.5, corresponding to the polyoxyethylene chain [28]. The average number of oxyethylene units in the polyoxyethylene chain can be estimated from the relative intensities of the different signals. In ${ }^{1} \mathrm{H} N M R$, the intensity of a signal is proportional to the number of protons creating that signal. Figure $8 \mathrm{~b}$ explains the spectrum of dodecyl phenol ethoxylate (DPE), which was estimated to have 13 as an average number of oxyethylene (OE) units adducted per dodecyl phenol molecule.

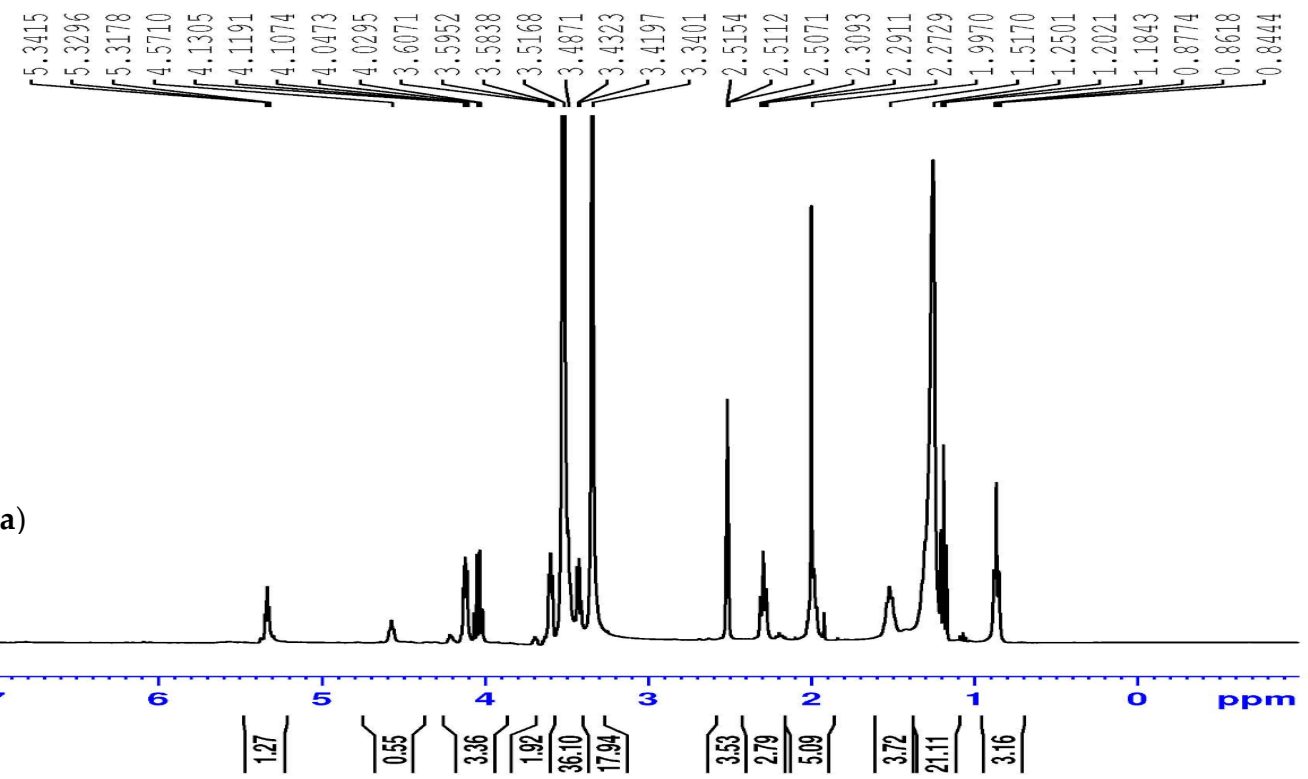

(b)

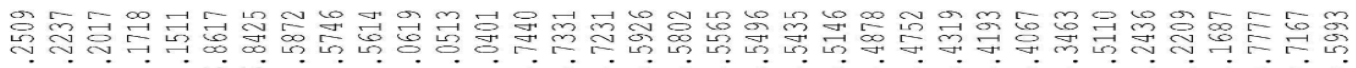

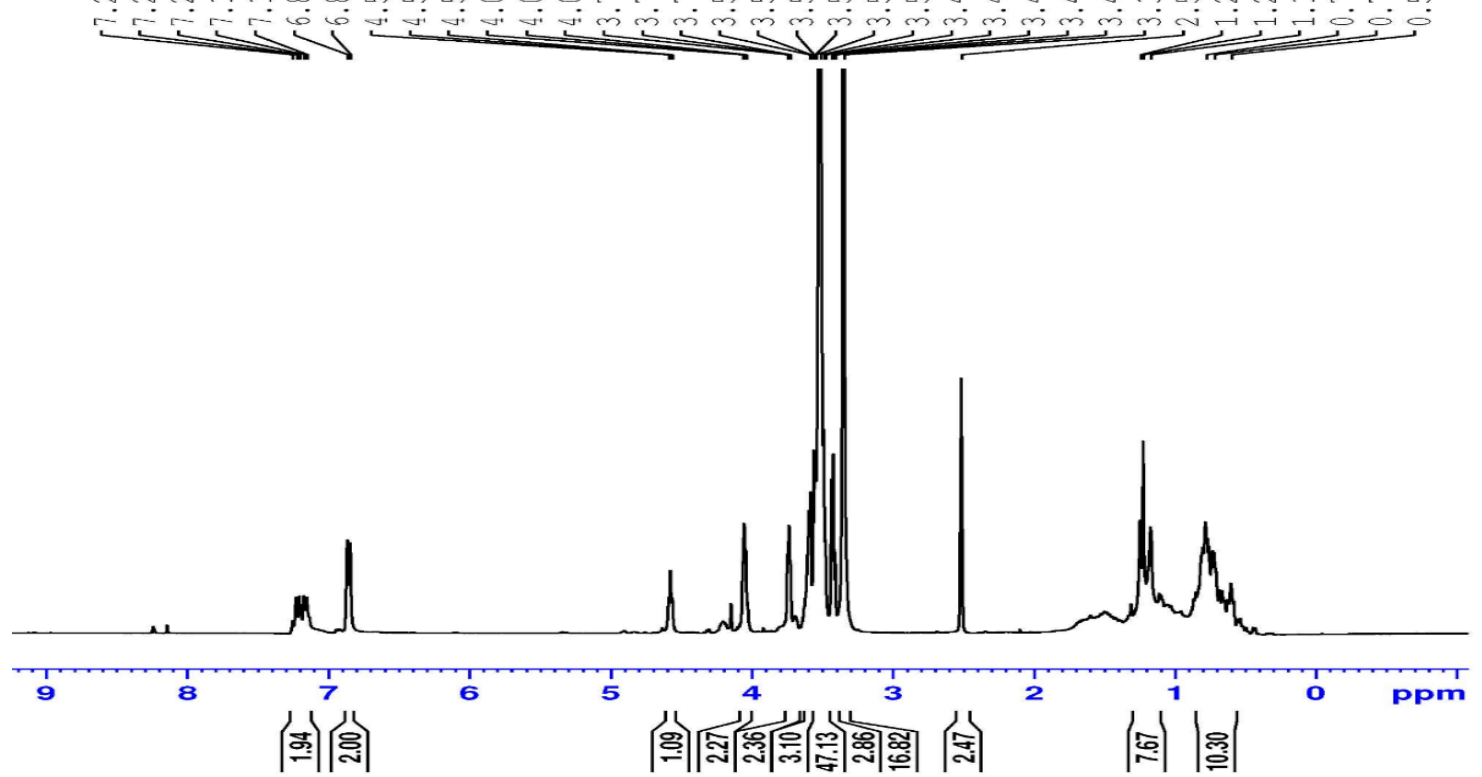

Figure 8. 1HNMR of (a) Scale inhibitor OAE, (b) Scale inhibitor DPE. 


\subsection{Membrane Scaling Evaluation}

\subsubsection{Permeability, Salt Rejection, and Permeate Flux Decline}

From previous scientific studies [34-36], it can be said that increasing the \% scales rejection aids in producing a nucleus that forms the calcite scale, which causes a decrease in the permeability of the used nanofiltration membrane in the desalination process. The use of antiscalants such as DPE and OAE in this study for the feeding water increases \% calcite scales rejection by chemical reaction and chemosorption process during the first nucleus, which forms the calcite scales on the surface of the NF membrane.

Generally, by using DPE and OAE during the PW treatment process, the \% scales rejection increases from $72 \%$ for blank TFCNF membrane reaching $97.2 \%$ and $88 \%$ for both DPE and OAE, respectively, as confirmed by data represented in Figure 9. This confirms that the calcite scales are formed in an abnormal brittle structure with a small amount that decreased the number of cleaning cycles of the NF membrane. Additionally, scale inhibitors DPE and OAE can form soluble coordinating stable salts during the treatment process, which positively affects the permeability of the nanofiltration membrane, as shown in Figure 9.

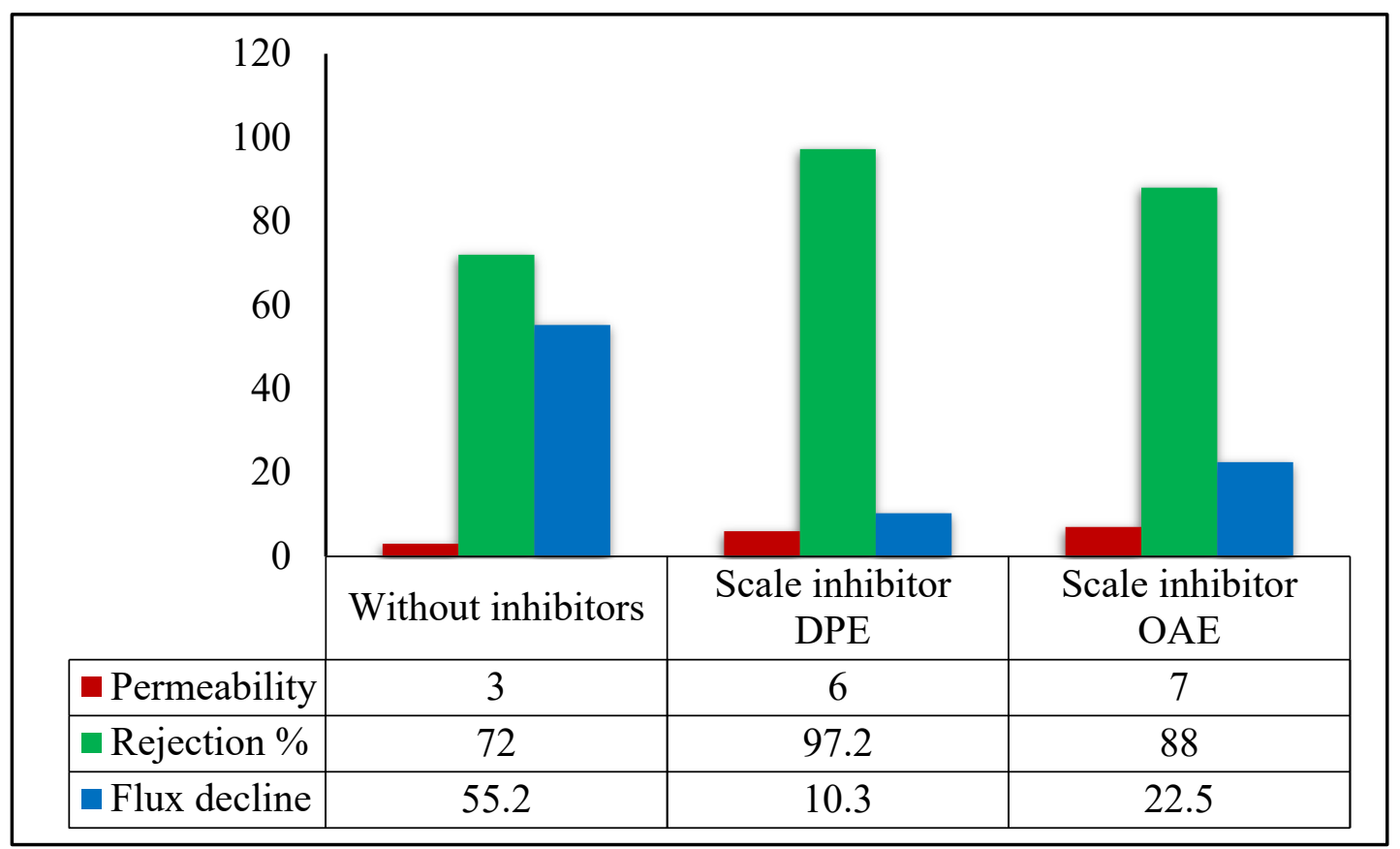

Figure 9. Membrane permeability, \% scale rejection, and Flux decline $\left(\mathrm{L} / \mathrm{m}^{2} \mathrm{~h}\right)$ for membrane, without inhibitor; with scale inhibitor DPE; and with scale inhibitor OAE.

DPE and OAE non-ionic surfactants are expected to increase membrane hydrophilicity. Contact angle tests showed a contact angle $\left(52^{\circ}\right)$ of the blank membrane TFCM membrane, reduced significantly to $26^{\circ}$ and $40^{\circ}$ for DPE and OAE, respectively, which confirms the higher efficiency of DPE. It was also observed that the normalized permeate flux $\left(\mathrm{L} / \mathrm{m}^{2} . \mathrm{h}\right)$ decreased to $0.78 \pm 0.01$; this equals to $55.2 \%$ flux decline. On the other hand, the permeate flux decreased by only $10.3 \%$ and $22.5 \%$ when using DPE and OAE, with no significant impact on the salt rejection capability of the membrane by the end of the scaling experiment. The obtained results of reaching the steady-state conditions $(150 \mathrm{~min})$ are shown in Figure 9.

The above results show that scale inhibitor DPE gives a better membrane permeability and high \% scales rejection with high scale inhibition efficiency than OAE in the same conditions. 


\subsubsection{Permeate Flux}

TFCNF membrane performance against calcite was evaluated by recirculating the prepared calcite solution and monitoring the decrease in flux caused by deposited scales during the experimental time. Figure 10 shows that scaling causes a flux decline over time.

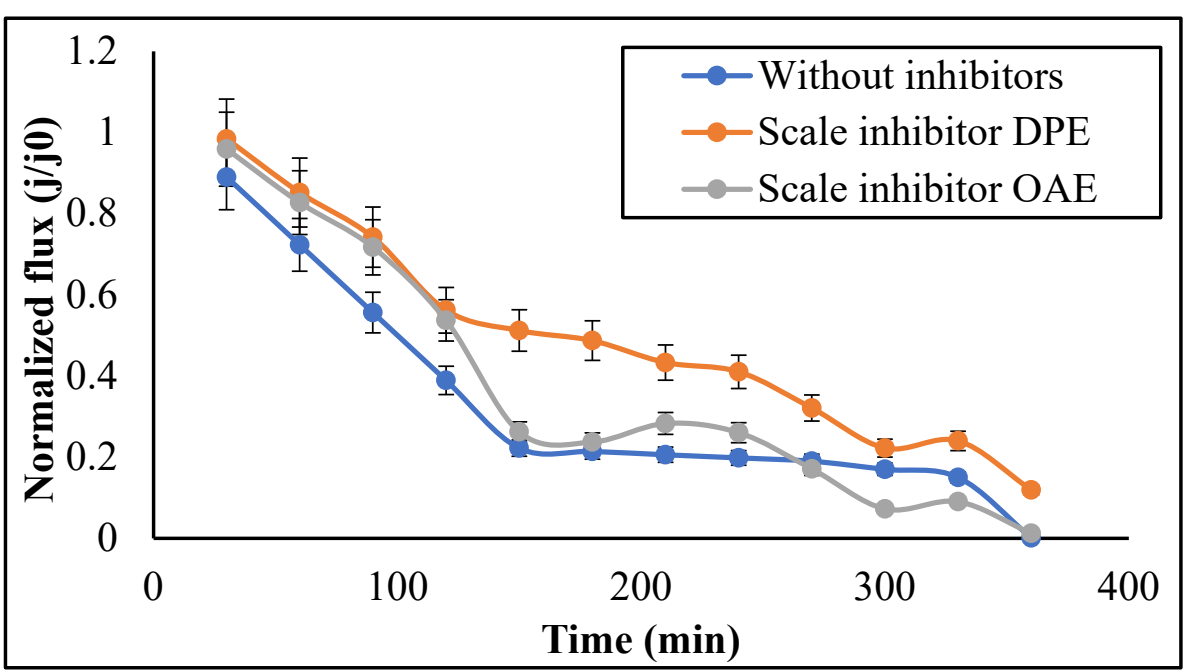

Figure 10. Permeate flux with time for TFCNF membrane without inhibitors, with scale inhibitor $\mathrm{DPE}$, and with scale inhibitor OAE (Flow rate $=1 \mathrm{~L} / \mathrm{h}$, temperature $=35 \pm 2{ }^{\circ} \mathrm{C}$, pressure $=32 \mathrm{bar}$ ).

Figure 10 shows the nanofiltration application of oilfield-produced water treatment. The figure shows that the scale inhibitor DPE inhibits transmembrane scaling pressure in the TFCNF membrane. This effect was confirmed by membrane scale characterization using SEM-EDX, FT-IR, and XRD. From this figure, the water flux drops sharply and finally reaches zero after $360 \mathrm{~min}$ with and without scale inhibitor OAE feed solution. In contrast, the water flux drop was significantly reduced during the $350 \mathrm{~min}$ continuous scaling test with the DPE scale inhibitor feed solution. Accordingly, by comparing the injection of the scale inhibitor OAE and DPE feed solutions with the same initial water flux, the lower water flux of the DPE feed solution for scale inhibitor is also lower during the membrane scaling test. These experiments demonstrate that the scale inhibitor DPE has been shown to have a higher enhancing effect on TFCNF filtration ability.

\subsubsection{Effect of $\mathrm{pH}$ Value on Calcite Scale Formation}

A series of experiments were performed with the feed water at different $\mathrm{pH}$ to investigate the effect of the initial $\mathrm{pH}$ of the feed water on the rejection rates of calcite by the NF membranes in Figure 11. It is clear from the figure that the rejection rate of calcite scales by the NF membrane was very low by the NF membrane. Only calcite scales were added to the feed tank (initial pH: 3.4). Initially, the rejection rate of calcite scales was about $60 \%$. Then it started to increase with increasing the $\mathrm{PH}$ value in the feed solution and finally stabilized at about $80 \%$. It was confirmed by repeating the experiment, similar results were obtained. However, when the $\mathrm{pH}$ of the feed water started to increase up to 10.0 by adding $\mathrm{NaOH}$ solution, the rate of calcite scales rejection by the NF membrane increased to $92.3,86.7,80 \%$ for OAE, DPE, and NF membrane. We can say that increasing the feed water's $\mathrm{pH}$ can enhance the NF membrane's rejection performance against calcite scales in an aqueous solution. So, there was an effective change observed between the two-scale inhibitors (DPE and OAE) feed solutions, more than the NF membrane without them. 


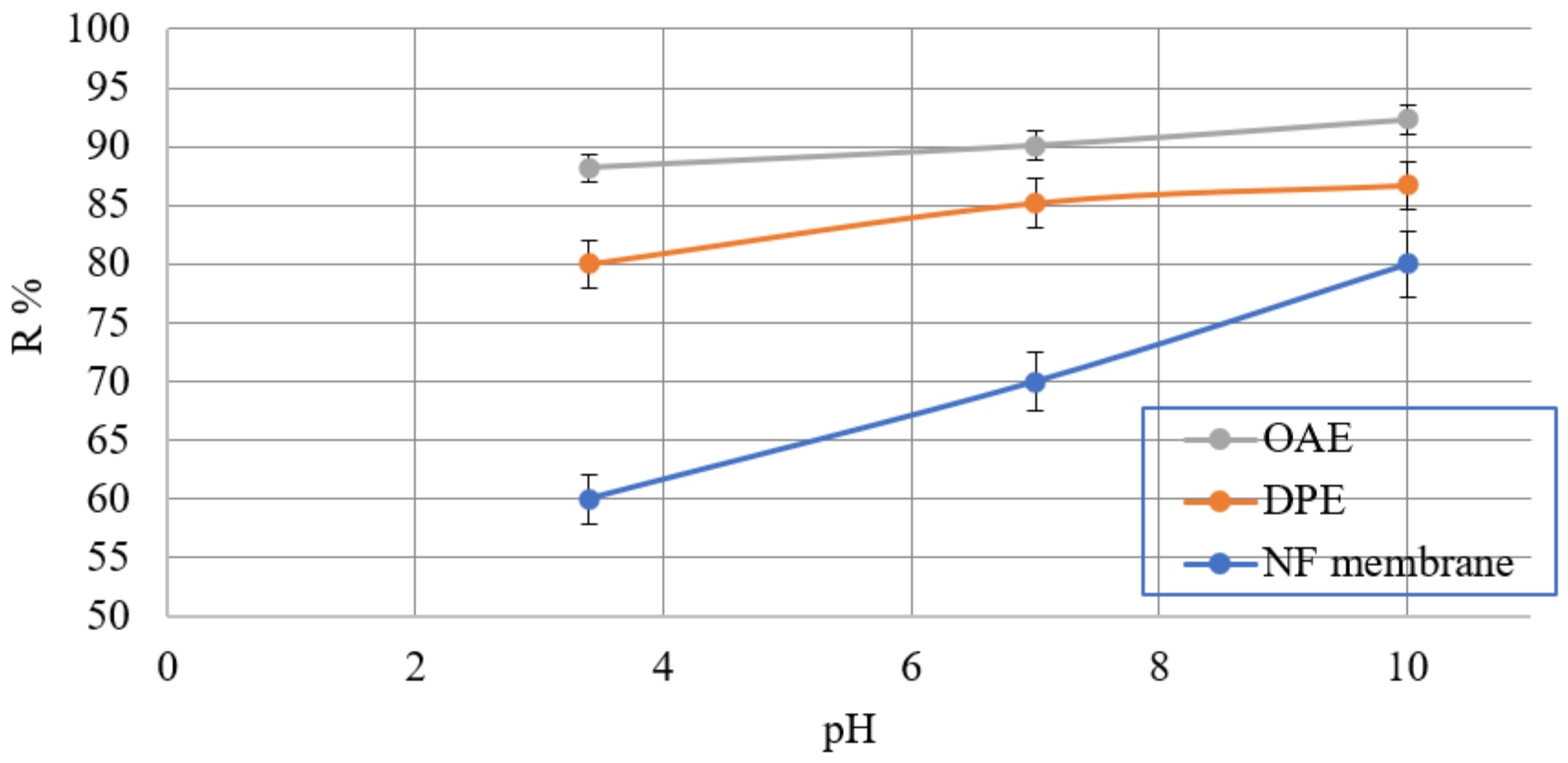

Figure 11. The rejection rates of calcite ions by NF membrane throughout the filtration tests at different initial feed water $\mathrm{pH}$ (Flow rate $=1 \mathrm{~L} / \mathrm{h}$, temperature $=35 \pm 2{ }^{\circ} \mathrm{C}$, pressure $=32$ bar).

\subsection{Simulation of $\mathrm{CaCO}_{3}$ Scaled Membrane}

Testing the scale layers formed on the thin-film composite membrane after the scaling experiment is important to explain the enhancing effect of the two inhibitors on the nanofiltration action and highlight the progress of the layering process. ESEM, XRD, and FTIR techniques were used.

\subsubsection{ESEM for Inhibited Scaled TFCNF Membrane after Injection the Scale Inhibitors}

Environmental scanning electron microscope (ESEM) images of a calcite scaled membrane without scale inhibitors injection; with scale inhibitors, DPE, and OAE injection are observed in Figure 12a-c. In all cases, there is a common observation that $\mathrm{CaCO}_{3}$ small crystals are formed. Calcite single crystal morphology shows a well-developed rhombohedral shape, characterized by straight and sharp edges (Figure 12a).

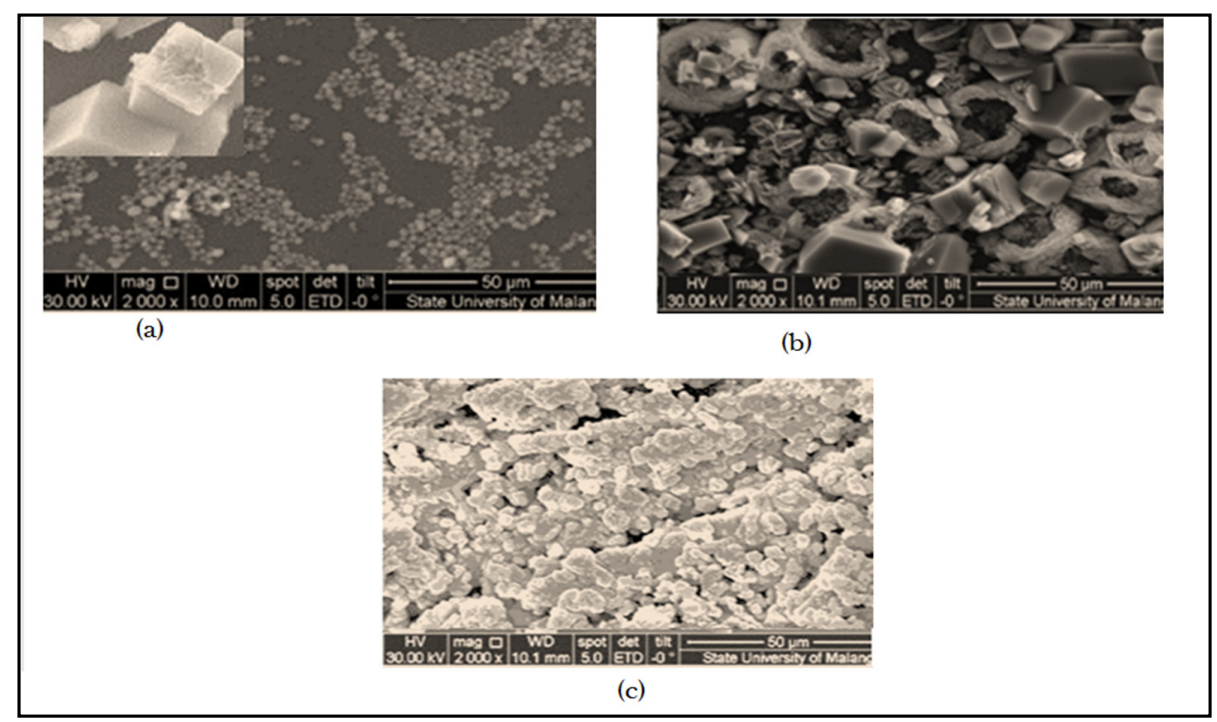

Figure 12. (a) ESEM of $\mathrm{CaCO}_{3}$ scaled membrane without scale inhibitors injection; (b) with scale inhibitor DPE injection, and (c) with scale inhibitor OAE injection. 
In the absence of a scale inhibitor, calcite crystals have an increased size, with a distorted shape showing rounded contours on the face perimeters (Figure 12a). Only the part facing the incoming flow appears in the well-established growth of rhombohedral calcite.

On the other hand, with injection scale inhibitors DPE, and OAE, although macroscopically, the $\mathrm{CaCO}_{3}$ scale deposits show a uniform distribution on the TFCNF membrane. The $\mathrm{CaCO}_{3}$ crystals are close to the exit in larger size compared with crystals close to the entry. This may be due to increasing concentration polarization as shown in Figure $12 b, c$, respectively.

\subsubsection{XRD Spectra of the Inhibited ScaledTFCNF Membrane}

XRD reveals important information about the inhibited scaled crystal structure, size, shape, and nature. Figure 13 shows XRD patterns of TFCNF membrane with and without scale inhibitors. It is clear from Figure 13 that for the scaled TFCNF membrane without inhibitors, two weak and broad peaks around 25 and 45 were observed, which are characterized for calcite scale. The spectra showed the calcite peak disappeared in the presence of the antiscalant.

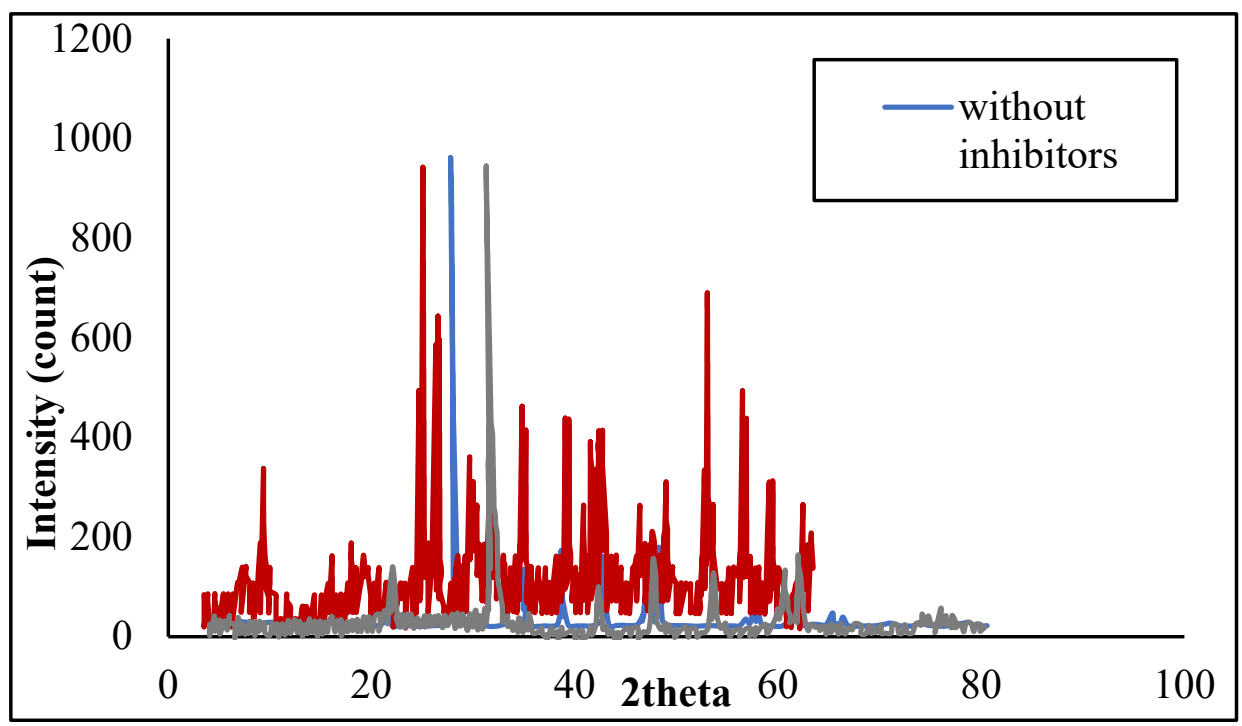

Figure 13. XRD of inhibited scaled TFCNF membrane without inhibitor; with scale inhibitor DPE injection; and with scale inhibitor OAE injection.

\subsubsection{FTIR Spectra of $\mathrm{CaCO}_{3}$ Scaled Membrane}

Different sites were sampled throughout the membrane surfaces and analyzed by FTIR to detect the nature of scales deposits.

In the current work, similar to the literature [37-39], the FTIR spectra suggested that the strong bands centered around $1140 \mathrm{~cm}^{-1}$ splitting into two components at around $1146 \mathrm{~cm}^{-1}, 1116 \mathrm{~cm}^{-1}$, and $669 \mathrm{~cm}^{-1}, 662 \mathrm{~cm}^{-1}$ represents stretching and bending modes of $\mathrm{CO}_{3}$ from pure calcite. An extensive scale layer formation is seen throughout nearly the entire membrane surface in all samples (Figure 14). In contrast, in DPE and OAE injection in feed-produced water, the calcite can be detected only towards the highly saturated zone in the flow exit region.

Calcite peaks at $1400 \mathrm{~cm}^{-1}, 1020 \mathrm{~cm}^{-1}, 1500 \mathrm{~cm}^{-1}$, and $1650 \mathrm{~cm}^{-1}$ attribute to polymorph of calcite precipitates, detected in both the highly saturated zone and throughout the filtration membrane surface. 


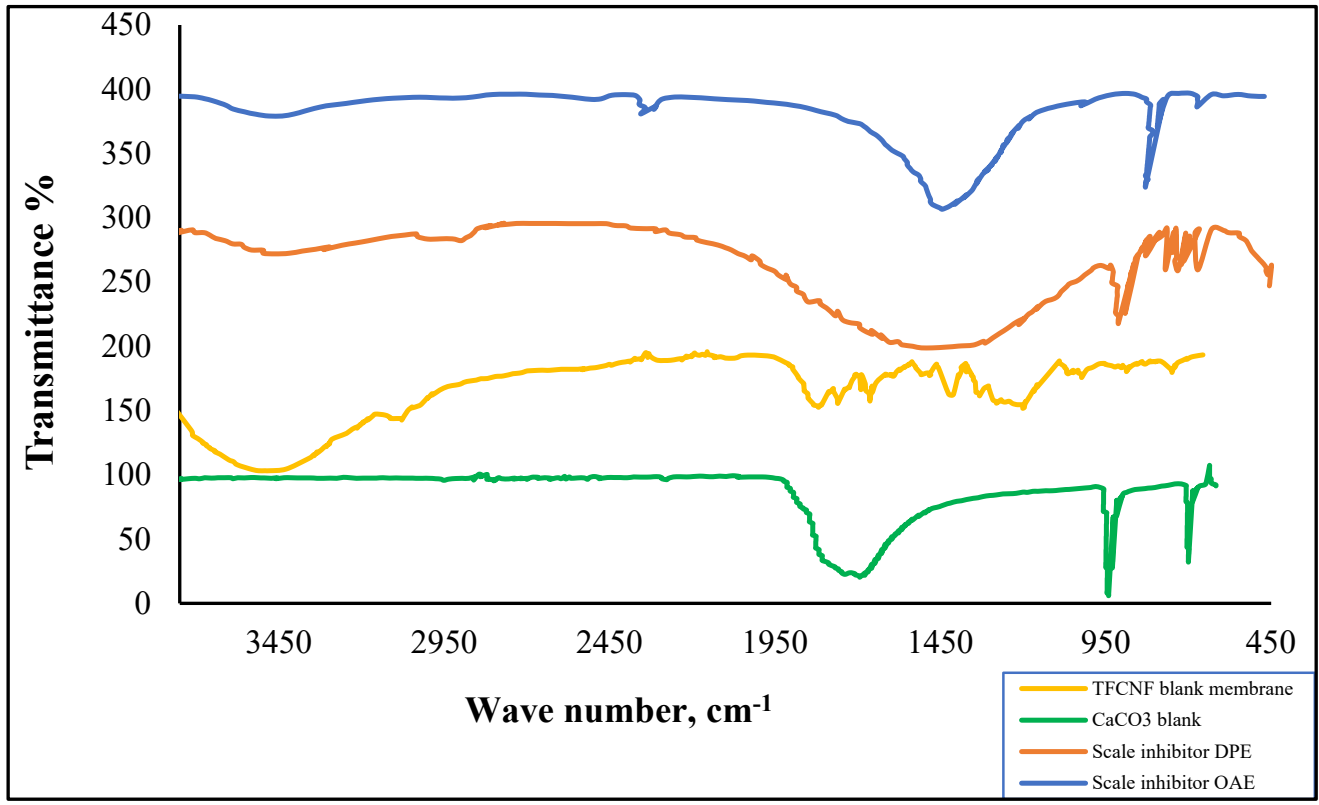

Figure 14. FTIR of TFCNF membrane (a) blank membrane; (b) scaled membrane without inhibitors; (c) with S.I. DPE injection; and (d) with S.I. OAE injection.

\subsubsection{Mechanism of Membrane Scaling Control with S.I. DPE and OAE}

As the schematic diagram (Figure 15) illustrates, the higher scaling-control efficiency using scale inhibitor DPE in feed solution can be due to the higher DPE concentrated near the filtration membrane surface. It is clear from Figure 15 that with the injection of scale inhibitors into the feed solution, DPE is chelated by $\mathrm{Ca}^{2+}$ in the bulk solution, resulting in the reduction of DPE concentration adjacent to the membrane surface.

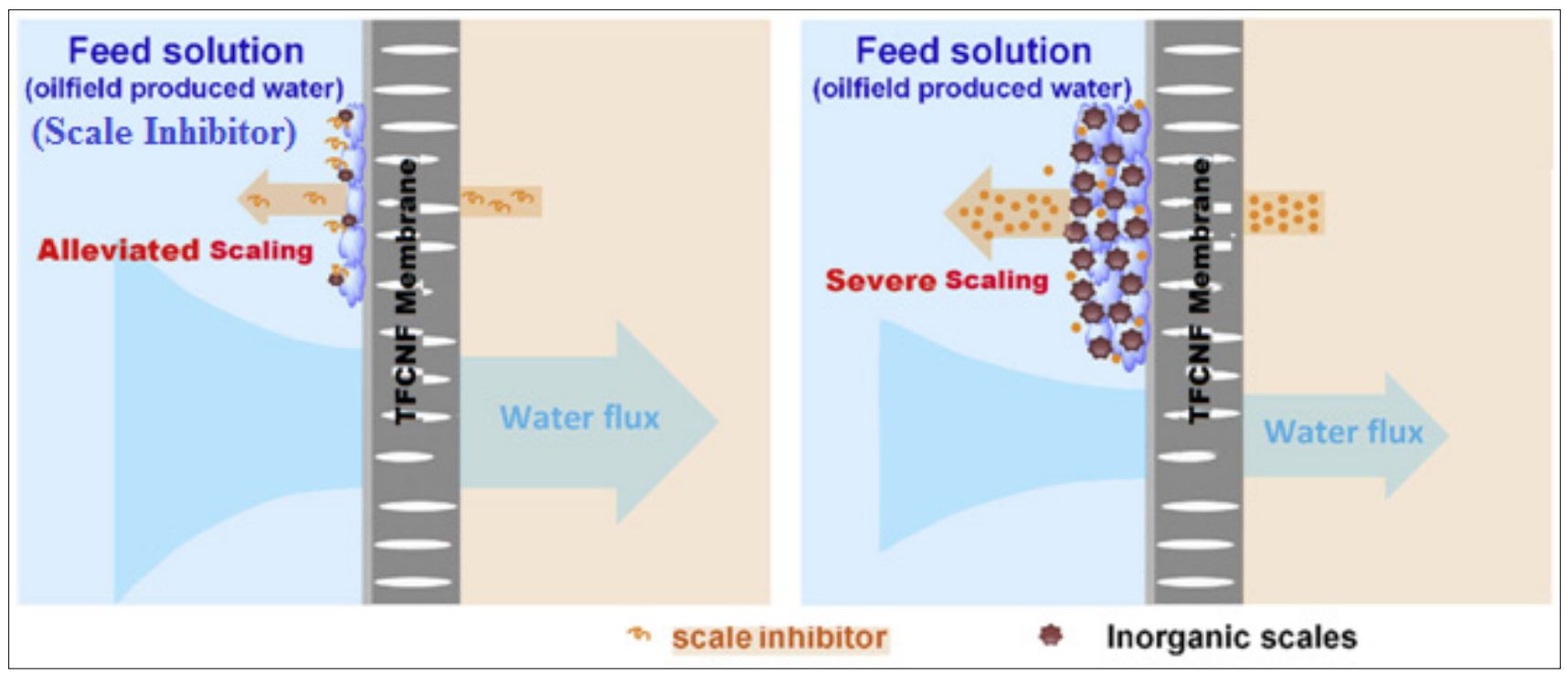

Figure 15. TFCNF membrane mechanism for reduced calcite with and without scale inhibitors in oilfield produced water.

Alternatively, with the DPE feed solution employed in the NF process, the diffusion of DPE draw solute from draw solution into the feed solution is continuous. Additionally, the concentration near the membrane surface is much higher than that in the bulk feed solution, which guarantees a better anti-scaling effect on the membrane. In addition, the leaked S.I.DPE draw solute adsorbed on the surface of the formed calcite crystals can further restrain the calcite crystal growth on the membrane surface effectively. Moreover, 
DPE can also cause the lattice distortion of calcite crystals [37], resulting in loose scales on the membrane surface, which a physical cleaning can easily wash away.

The improved anti-scaling performance of the TFCNF membrane rises from better hydrophilicity and thus surface smoothness. Soanenergy barrier would develop against calcite surface nucleation or deposition on the membrane surface. Moreover, the repulsive forces between the negative charges of scale inhibitors and calcite ions may have played an important role in discouraging fouling on the membrane [38].

\subsection{Comparison of OAE and DPE with Other Scale Inhibitors}

In Table 2, our results are compared with the previous work summarizing the efficiency of scale inhibitors to prove the effectiveness of OAE and DPE as calcite scale inhibitors. Their effectiveness was compared to the scale inhibitors as salt rejection \%. It is clear from this comparison that the scale inhibitor DPE can be used as an effective scale inhibitor during the anti-scaling membrane process, as it has a high percentage of rejected salts $\%$. Features of different S.Is., such as structure, functional groups, and surface areas, are attributed to differences in scale inhibition ability [39].

Table 2. Comparison of OAE and DPE efficiency with some calcite scale inhibitors of previous studies.

\begin{tabular}{ccc}
\hline Antiscalant & Salt Rejection (\%) & Ref. \\
\hline AA-APEC & $96 \%$ & {$[40]$} \\
CM-QAOC & $70.2 \%$ & {$[41]$} \\
Palm leaves extract & $89.7 \%$ & {$[42]$} \\
PASP/Cs & $92 \%$ & {$[43]$} \\
PAA & $82.7 \%$ & {$[44]$} \\
AA-APEC & $83.6 \%$ & {$[44]$} \\
CG & $91 \%$ & {$[45]$} \\
OAE & 88 & This study \\
DPE & 97.2 & This study \\
\hline
\end{tabular}

\section{Conclusions}

This paper aims to reduce the calcium carbonate scales from PW precipitated in oilfield production pipelines to enhance oil production. TFCNF membrane was prepared and its function was enhanced via the injection of two new scale inhibitors (DPE and OAE). Using scale inhibitors, filtration experiments revealed that the flux decline is only $15 \%$ in the presence of the scale inhibitors, whereas the flux decline in the TFCNF membrane is $22 \%$. SEM shows no precipitates were observed on the membrane.

According to the results of FT-IR and XRD measurements performed on the scaled membrane, the presence of precipitates was restricted to only highly saturated zones (i.e., zones near the end of the water flow channel) on the membrane. The injection of scale inhibitors DPE into the feeding solution can effectively reduce calcite scales' formation on the surface of the TFCNF membrane. This is attributed to the fact that it has excellent scale inhibiting ability as well as unique diffusion. This research may result in a practical strategy for membrane scaling control in the NF application of produced water treatment and a comprehensive understanding of the subject.

Author Contributions: M.F.M., the main idea of the paper. M.A., preparation and characterization of scale inhibitors. R.H., M.F.M. and O.H.A., participation in the practical application of the prepared materials and the work of laboratory tests for them. M.A. writing preparation part and interpretation of its data analysis. R.H. and M.F.M., interpretation of application, paper writing, and paper revision. R.H., M.F.M., M.A., M.A.Z. and O.H.A. review and editing. Conceptualization, A.H.R., S.R.A.-M. and R.H.; methodology, A.H.R., S.R.A.-M. and O.H.A.; software, A.E.S.; validation, O.H.A., A.E.S. and S.R.A.-M.; formal analysis, S.R.A.-M.; investigation, M.F.M.; resources, A.E.S. and S.R.A.-M.; data curation, A.H.R. and S.R.A.-M.; writing-original draft preparation, A.H.R. and S.R.A.-M.; writing-review and editing, A.E.S., M.F.M. and R.H.; visualization, O.H.A.; supervision, R.H., 
project administration, M.F.M.; funding acquisition, A.H.R. and S.R.A.-M. All authors have read and agreed to the published version of the manuscript.

Funding: This research was assisted funded by the Dean of Science and Research at King Khalid University via the General Research Project: Grant no. (R.G.P.1/355/42).

Acknowledgments: The authors are grateful to the Dean of Science and Research at King Khalid University for making financial support available and thank the Egyptian Petroleum Research Institute for making the practical analysis. I would like to thank everyone in the Water Desalination Group in the Egyptian Petroleum Research Institute [EPRI] for their efforts to produce that paper.

Conflicts of Interest: The authors declare no conflict of interest.

\section{Abbreviations}

$\begin{array}{ll}\text { S.I. } & \text { Scale Inhibitor } \\ \text { NF } & \text { Nanoafiltration } \\ \text { TFCNF } & \text { Thin-film composite nanofiltration membrane } \\ \text { FT-IR } & \text { Forior transform IR } \\ \text { XRD } & \text { X-ray diffraction } \\ \text { ESEM } & \text { Environmental scanning electron } \\ \text { DP } & \text { Dodecyl phenol } \\ \text { DPE } & \text { Dodecyl phenol ethoxylate } \\ \text { OA } & \text { Oleic acid } \\ \text { OAE } & \text { Oleic acid ethoxylate } \\ \text { PW } & \text { Produced water } \\ \text { Na } 2 \text { CO } 3 & \text { Sodium carbonate } \\ \text { CaCl } 2 & \text { Calcium chloride } \\ \text { DMAc } & \text { Dimethyl-acetamide } \\ \text { DCM } & \text { Dichloromethane } \\ \text { OcA } & \text { Octylamine } \\ \text { OcDA } & \text { Octadecylamine } \\ \text { PVDF } & \text { Poly-vinylidene fluoride } \\ \text { AA-APEC } & \text { Acrylic acid allylpolyethoxy carboxylate } \\ \text { CM-QAOC } & \text { Carboxymethyl quaternary ammonium oligochitosan } \\ \text { PASP/Cs } & \text { Polyaspartic acid/chitosan } \\ \text { PAA } & \text { Polyacrylic acid } \\ \text { CG } & \text { Chitosan biguanidine hydrochloride } \\ & \end{array}$

\section{References}

1. Nasiri, M.; Jafari, I. Produced water from oil-gas plants: A short review on challenges and opportunities. Period. Polytech. Chem. Eng. 2017, 61, 73-81. [CrossRef]

2. Coday, B.D.; Xu, P.; Beaudry, E.G.; Herron, J.; Lampi, K.; Hancock, N.T.; Cath, T.Y. The sweet spot of forward osmosis: Treatment of produced water, drilling wastewater, and other complex and difficult liquid streams. Desalination 2014, 333, 23-35. [CrossRef]

3. Fakhru'1-Razi, A.; Pendashteh, A.; Abdullah, L.C.; Biak, D.R.A.; Madaeni, S.S.; Abidin, Z.Z. Review of technologies for oil and gas produced water treatment. J. Hazard. Mater. 2009, 170, 530-551. [CrossRef]

4. Oyeneyin, B. Introduction to the hydrocarbon composite production system. In Developments in Petroleum Science; Elsevier: Amsterdam, The Netherlands, 2015; Volume 63, pp. 11-128.

5. Moghadasi, J.; Jamialahmadi, M.; Müller-Steinhagen, H.; Sharif, A. Formation damage due to scale formation in porous media resulting from water injection. In Proceedings of the SPE International Symposium and Exhibition on Formation Damage Control, Lafayette, LA, USA, 18-20 February 2004.

6. Capodaglio, A.; Callegari, A.; Cecconet, D.; Molognoni, D. Sustainability of decentralized wastewater treatment technologies. Water Pract. Technol. 2017, 12, 463-477. [CrossRef]

7. Pan, Z.; Song, C.; Li, L.; Wang, H.; Pan, Y.; Wang, C.; Li, J.; Wang, T.; Feng, X. Membrane technology coupled with electrochemical advanced oxidation processes for organic wastewater treatment: Recent advances and future prospects. Chem. Eng. J. 2019, 376, 120909. [CrossRef]

8. Morillo, J.; Usero, J.; Rosado, D.; El Bakouri, H.; Riaza, A.; Bernaola, F.-J. Comparative study of brine management technologies for desalination plants. Desalination 2014, 336, 32-49. [CrossRef]

9. Al-Amoudi, A.S. Factors affecting natural organic matter (NOM) and scaling fouling in NF membranes: A review. Desalination 2010, 259, 1-10. [CrossRef] 
10. Bush, J.A.; Vanneste, J.; Cath, T.Y. Membrane distillation for concentration of hypersaline brines from the Great Salt Lake: Effects of scaling and fouling on performance, efficiency, and salt rejection. Sep. Purif. Technol. 2016, 170, 78-91. [CrossRef]

11. Ashfaq, M.Y.; Al-Ghouti, M.A.; Zouari, N. Functionalization of reverse osmosis membrane with graphene oxide to reduce both membrane scaling and biofouling. Carbon 2020, 166, 374-387. [CrossRef]

12. Qingfeng, $\mathrm{Y}$. Inhibition of $\mathrm{CaCO}_{3}$ scaling in reverse osmosis system by zinc ion. Chin. J. Chem. Eng. 2006, 14, 178-183.

13. LI, Y.; ZHOU, B.; SHI, Y.; Wang, X. Survey of researches on reveres osmosis scale inhibitor. Ind. Water Treat. $2004,24,17-21$.

14. Lei, W.; Wang, F.Y.; Xia, M.Z.; Wang, F. Synthesis and its scale inhibition effect of green scale inhibitor polyepoxysuccinic acid. J. Chem. Ind. Eng. China 2006, 57, 2207.

15. Ramzi, M.; Hosny, R.; El-Sayed, M.; Fathy, M.; Moghny, T.A. Evaluation of scale inhibitors performance under simulated flowing field conditions using dynamic tube blocking test. Int. J. Chem. Sci. 2016, 14, 16-28.

16. Sousa, M.F.; Bertran, C.A. New methodology based on static light scattering measurements for evaluation of inhibitors for in bulk $\mathrm{CaCO}_{3}$ crystallization. J. Colloid Interface Sci. 2014, 420, 57-64. [CrossRef] [PubMed]

17. Shahid, M.K.; Choi, Y.-G. The comparative study for scale inhibition on surface of RO membranes in wastewater reclamation: $\mathrm{CO}_{2}$ purging versus three different antiscalants. J. Membr. Sci. 2018, 546, 61-69. [CrossRef]

18. Hosny, R.; Fathy, M.; Ramzi, M.; Moghny, T.A.; Desouky, S.E.; Shama, S.A. Treatment of the oily produced water (OPW) using coagulant mixtures. Egypt. J. Pet. 2016, 25, 391-396. [CrossRef]

19. Hilal, N.; Ogunbiyi, O.O.; Miles, N.J.; Nigmatullin, R. Methods employed for control of fouling in MF and UF membranes: A comprehensive review. Sep. Sci. Technol. 2005, 40, 1957-2005. [CrossRef]

20. Amjad, Z.; Demadis, K.D. Mineral Scales and Deposits: Scientific and Technological Approaches; Elsevier: Amsterdam, The Netherlands, 2015.

21. Al-Zoubi, H.; Rieger, A.; Steinberger, P.; Pelz, W.; Haseneder, R.; Härtel, G. Optimization study for treatment of acid mine drainage using membrane technology. Sep. Sci. Technol. 2010, 45, 2004-2016. [CrossRef]

22. Knoell, T.; Patel, M.; Neely, T.; Dunivin, W.; Owens, E. Identifying, evaluating, and implementing antiscalants in RO reuse applications. IDA J. Desalination Water Reuse 2011, 3, 12-16. [CrossRef]

23. Spinthaki, A.; Demadis, K.D. Chemical methods for scaling control. In Corrosion and Fouling Control in Desalination Industry; Springer: Cham, Switzerland, 2020; pp. 307-342.

24. Ying, G.-G.; Williams, B.; Kookana, R. Environmental fate of alkylphenols and alkylphenol ethoxylates-A review. Environ. Int. 2002, 28, 215-226. [CrossRef]

25. White, G.F. Bacterial biodegradation of ethoxylated surfactants. Pestic. Sci. 1993, 37, 159-166. [CrossRef]

26. Barakat, Y.M.A.; Ibrahim, V. Surfactants with Natural Hydrophobic Tails Polyoxyethylenated Cholesterol-Surface Tension and CMC. J. Appl. Sci. Res. 2010, 6, 1273-1290.

27. Longman, G.F. Analysis of Detergents and Detergent Products; Wiley: London, UK, 1976.

28. Tyman, J.H.; Bruce, I.E. Synthesis and characterization of polyethoxylate surfactants derived from phenolic lipids. J. Surfactants Deterg. 2003, 6, 291-297. [CrossRef]

29. Gao, L.; Alberto, M.; Gorgojo, P.; Szekely, G.; Budd, P.M. High-flux PIM-1/PVDF thin film composite membranes for 1butanol/water pervaporation. J. Membr. Sci. 2017, 529, 207-214. [CrossRef]

30. Curcio, E.; Fontananova, E.; Di Profio, G.; Drioli, E. Influence of the structural properties of poly(vinylidene fluoride) membranes on the heterogeneous nucleation rate of protein crystals. J. Phys. Chem. B 2006, 110, 12438-12445. [CrossRef] [PubMed]

31. Ang, M.B.M.Y.; Tang, C.-L.; De Guzman, M.R.; Maganto, H.L.C.; Caparanga, A.R.; Huang, S.-H.; Tsai, H.-A.; Hu, C.-C.; Lee, K.-R.; Lai, J.-Y. Improved performance of thin-film nanofiltration membranes fabricated with the intervention of surfactants having different structures for water treatment. Desalination 2020, 481, 114352. [CrossRef]

32. Benhabiles, O.; Galiano, F.; Marino, T.; Mahmoudi, H.; Lounici, H.; Figoli, A. Preparation and characterization of TiO2PVDF/PMMA blend membranes using an alternative non-toxic solvent for UF/MF and photocatalytic application. Molecules 2019, 24, 724. [CrossRef] [PubMed]

33. Wang, F.; Chen, J.; Hong, H.; Wang, A.; Lin, H. Pollutant removal and membrane fouling in an anaerobic submerged membrane bioreactor for real sewage treatment. Water Sci. Technol. 2014, 69, 1712-1719. [CrossRef]

34. Liu, Q.; Xu, G.-R.; Das, R. Inorganic scaling in reverse osmosis (RO) desalination: Mechanisms, monitoring, and inhibition strategies. Desalination 2019, 468, 114065. [CrossRef]

35. Wang, Y. Composite Fouling of Calcium Sulfate and Calcium Carbonate in a Dynamic Seawater Reverse Osmosis Unit; University of New South Wales: Sydney, Australia, 2005.

36. Piyadasa, C.; Ridgway, H.F.; Yeager, T.R.; Stewart, M.B.; Pelekani, C.; Gray, S.R.; Orbell, J.D. The application of electromagnetic fields to the control of the scaling and biofouling of reverse osmosis membranes-A review. Desalination 2017, 418, 19-34. [CrossRef]

37. Chua-Anusorn, W.; St Pierre, T. Pathological biomineralization of iron. In Biomineralization-Medical Aspects of Solubility; John Wiley and Sons, Ltd.: Chichester, UK, 2006; pp. 219-267.

38. Shen, D.; Zhang, P.; Kan, A.T.; Fu, G.; Alsaiari, H.A.; Tomson, M.B. Control placement of scale inhibitors in the formation with stable Ca-DTPMP nanoparticle suspension and its transport in porous medium. In Proceedings of the SPE International Oilfield Scale Conference, Aberdeen, UK, 28-29 May 2008.

39. Ali, S.A.; Haladu, S.A.; Mazumder, M.A.; Al-Muallem, H.A. Synthesis of a terpolymer and a tetrapolymer using monomers of diallylamine salts and $\mathrm{SO}_{2}$ and their application as antiscalants. Iran. Polym. J. 2016, 25, 747-756. [CrossRef] 
40. Cao, K.; Huang, J.; Zhou, Y.; Liu, G.; Wang, H.; Yao, Q.; Liu, Y.; Sun, W.; Wu, W. A multicarboxyl antiscalant for calcium phosphate and calcium carbonate deposits in cooling water systems. Desalination Water Treat. 2014, 52, 7258-7264. [CrossRef]

41. Zhang, H.; Cai, Z.; Jin, X.; Sun, D.; Wang, D.; Yang, T.; Zhang, J.; Han, X. Preparation of modified oligochitosan and evaluation of its scale inhibition and fluorescence properties. J. Appl. Polym. Sci. 2015, 132, 42518. [CrossRef]

42. Abd-El-Khalek, D.; Abd-El-Nabey, B.; Abdel-kawi, M.A.; Ramadan, S. Investigation of a novel environmentally friendly inhibitor for calcium carbonate scaling in cooling water. Desalination Water Treat. 2016, 57, 2870-2876. [CrossRef]

43. Zeng, D.; Chen, T.; Zhou, S. Synthesis of polyaspartic acid/chitosan graft copolymer and evaluation of its scale inhibition and corrosion inhibition performance. Int. J. Electrochem. Sci. 2015, 10, 9513-9527.

44. Xue, X.; Fu, C.; Li, N.; Zheng, F.; Yang, W.; Yang, X. Performance of a non-phosphorus antiscalant on inhibition of calcium-sulfate precipitation. Water Sci. Technol. 2012, 66, 193-200. [CrossRef]

45. Maher, Y.A.; Ali, M.E.A.; Salama, H.E.; Sabaa, M.W. Preparation, characterization and evaluation of chitosan biguanidine hydrochloride as a novel antiscalant during membrane desalination process. Arab. J. Chem. 2020, 13, 2964-2981. [CrossRef] 